\title{
Rational Design of Duplex Specific Nuclease for One-Step Isothermal Viral RNA Detection
}

\author{
Elizabeth M. Wurtzler, Ranjani Ravi, Vikram Kapoor, David Wendell* \\ Department of Biomedical, Chemical and Environmental Engineering University of Cincinnati 705 Engineering Research Center 2901 Woodside Dr \\ Cincinnati, $\mathrm{OH}$.
}

\section{ARTICLE INFO}

Article history:

Received on: 04/11/2016

Accepted on: 07/04/2017

Available online: 30/10/2017

Key words:

Duplex specific nuclease;

norovirus; viral detection; RNA;

RNA detection; environmental

water.

\begin{abstract}
RNA viruses are a potent human adversary, evidenced by several global pandemics including the Ebolavirus in West Africa, the emerging Zika virus, and outbreaks of new Influenza strains and Norwalk virus in the food supply and cruise ships. Despite the virulence of these pathogens, there remains a significant limitation for detecting these viruses in a fast, accurate and cost effective manner. To meet this need we present a modified form of the duplex specific nuclease enzyme from the Paralithodes camtschaticus crab capable of generating an RNA-based signal amplification in a fraction of the time required for standard RT-qPCR. The applicability of this enzyme is demonstrated in an assay for Norwalk virus detection with a lower limit of $\sim 100$ viral copies per liter of environmental water.
\end{abstract}

\section{INTRODUCTION}

RNA detection can provide a wealth of information used to diagnose diseases [1-3], track cellular growth and development, infections, pollution, as well as many other "omics" applications [4-6]. RT-qPCR remains the gold standard for RNA quantification; however, this technique is limited by time and equipment constraints and can be prone to contamination. To minimize these limitations, isothermal RNA amplification techniques have been developed [7-14], but these still remain dependent on nucleic acid replication and are therefore hindered by polymerase speed and fidelity. Recent RNA detection methods that have employed duplex specific nuclease (DSN) isolated from the Paralithodes camtschaticus crab [15, 16], remain limited to microRNA [17] and are thus unsuitable for longer RNA templates like virus genomic or mRNA targets. DSN is an attractive candidate for the latter, since it preferentially cleaves DNA in a DNA-RNAduplex, leaving ssRNA and dsRNA virtually unchanged [15]. DSN acts as an endonuclease on DNA, cleaving within the phosphate backbone [16], although the direction of digestion is unknown. The enzyme's preference for

\footnotetext{
* Corresponding Author
}

Email: endeldw@uc.edu
DNA has also been applied for many techniques using short RNA sequences [16, 18-29], but applications for long RNA targets have remained elusive.

Norovirus (species Norwalk virus, genus Norovirus, family Caiciviridae, order unassigned) was chosen to develop our DSN assay due to its ubiquity, persistent outbreaks, and reduced virulence compared to other recent pandemic viruses. Worldwide, Norwalk virus is the most common cause of gastroenteritis [4046], accounting for almost $20 \%$ of these cases [47], resulting in 71,000 hospitalizations [48] and approximately 800 deaths per year in the United States [41, 49]. The infectious dose of norovirus is extremely low, around 18 viral particles [50], making it highly contagious and readily transmitted in environments with close interpersonal contact [51-53]. Further, norovirus particles can retain infectivity in ground water for at least two months with viral RNA detectable for up to three years [54]. Given the infectivity and persistence of norovirus, methods to detect viruses in water are of paramount importance to prevent future infections. However, given the limited laboratory options for propagation of norovirus $[55,56]$ and commercial kits for rapid diagnosis remain underdeveloped [57, 58]. As a result, clinical laboratories commonly use reverse transcription-polymerase chain reaction (RT-PCR), immunoassays or hybridization assays [59-62], which can lead to false positives, provide lower sensitivities and require significant time and materials costs [62-70]. 
Clearly, there is a need for a sensitive, rapid, more cost effective norovirus detection method. Applying the unique nuclease activity of DSN to broad range RNA detection is limited by the relatively short RNA template range $(<20 \mathrm{nt})$, similar to the RISC complex [71], and the reported production/purification difficulty. Here, we report a screening investigation of nuclease inhibitors to challenge DSN to recognize longer RNA templates, which led us to recombinant production of structurally modified DSN that functions without inhibitors on the same larger RNA templates. Targeted point mutations were made based on the predicted secondary structure of DSN, sequence alignment with other nucleases, and the theoretical structural interactions of inhibitors with specific amino acid motifs. Successful detection of norovirus RNA targets was achieved using fluorescently labeled Taqman probes (Figure 1).

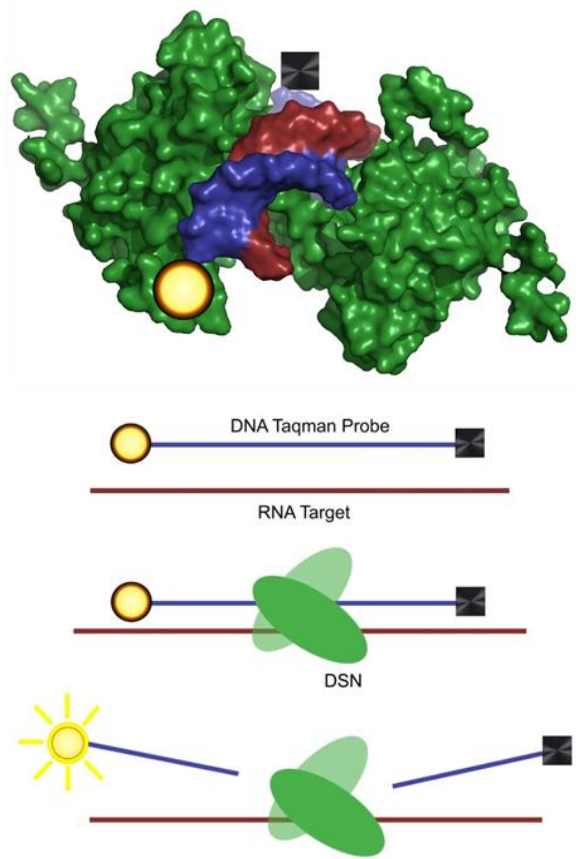

Fig. 1: Schematic representation of Norovirus RNA detection based on Duplex-Specific Nuclease. Nuclease activity of DSN digesting the DNA Taqman probe, which provides the fluorescent signal for analyte detection (left). The Taqman-based DNA probes hybridize with the viral RNA template to form a DNA:RNA hybrid and allow DSN to specifically digest the DNA probe within the duplex, generating a fluorescent signal upon the separation of quencher and reporter dye (right).

\section{MATERIAL AND METHODS}

All chemicals and reagents were purchased from Sigma unless otherwise noted.

\subsection{RNA OLIGONUCLEOTIDES AND DNA PROBES}

Short RNA oligonucleotides and probes (Table 1) corresponding to the norovirus genogroups GI and GII were synthesized (Operon, USA). The probe sequences were obtained from Hoehne et al. with required modifications to ensure the absence of secondary structure formation using RNA fold [72].
The probes were designed to have an annealing temperature of $60^{\circ} \mathrm{C}$, the optimum working temperature for the DSN enzyme. The GI probe was labeled at 5'-end with Cyanine3 (Cy3 fluorophore) and at the 3'-end with BHQ (Black Hole Quencher). The GII probe contained 6-FAM (6-carboxyfluorescein) and BHQ at the 5' and 3 ends, respectively.

Table 1: Sequence of RNA Oligos and Taqman ${ }^{\mathrm{TM}}$ Probes used in this work.

\begin{tabular}{lll}
\hline \multicolumn{1}{c}{ Name } & \multicolumn{1}{c}{ Sequence (5'-3') } & Location* \\
\hline NVGI RNA & AAAUGAUGAUGGCGUCUAAGGACG & $5355-5379$ \\
NVGI probe & Cy3-CCTTAGACGCCATCATCA-BHQ & $5376-5359$ \\
NVGII RNA & UGUGAAUGAAGAUGGCGUCGAAUG & $5080-5103$ \\
NVGII probe & 6-FAM-TCGACGCCATCTTCATTC-BHQ & $5100-5083$ \\
\hline
\end{tabular}

Cy3:Cyanine3 BHQ:Black Hole Quencher 6-FAM: 6-Fluorescein amidite

$*$ Genome location of sequences are based for GI on the sequence of

Norwalk/68/US [GenBank: M87661] and for GII on the sequence of

Lordsdale/93/UK [GenBank: X86557]

\subsection{DSN BASED DETECTION FOR RNA OLIGONUCLEOTIDES}

For the DSN assay, $25 \mu \mathrm{l}$ reaction was prepared containing 1x DSN buffer A (50mMTris-HCl, pH 8.0;7mM $\mathrm{MgCl}_{2}, 1 \mathrm{mM}$ DTT), 0.1U DSN enzyme (dissolved in $25 \mathrm{mMTris}$ $\mathrm{HCl}, \mathrm{pH} 8.0 ; 50 \%$ glycerol), RNA mixture and complimentary probe $(50 \mathrm{nM})$. The final reaction mixture was incubated at $60^{\circ} \mathrm{C}$ for $25 \mathrm{~min}$. Subsequently, $25 \mu \mathrm{l} 10 \mathrm{mMEDTA}$ was added to the reaction mixture and incubated at $60^{\circ} \mathrm{C}$ for $5 \mathrm{~min}$ to inactivate the DSN enzyme and end point fluorescence was recorded.10-10,000 copies per $25 \mu \mathrm{l}$ reaction with additional no template controls were examined in triplicate. Dilution series for each of the synthetic RNAs were made in either RNase and DNase-free $\mathrm{H}_{2} \mathrm{O}$ or environmental RNA solution to provide a constant background of nonspecific RNA. Enzyme activity ratios were generated by normalizing the signal relative to the minimal fluorescence generated by the template free controls.

\subsection{OPTIMIZED DSN REACTION}

A volume of $25 \mu \mathrm{L}$ reaction mixture containing $1 \mathrm{x}$ DSN buffer B (50 mMTris-HCl, pH 8.0;10mM $\mathrm{MgCl}_{2}, 1 \mathrm{mM}$ DTT), $0.1 \mathrm{U}$ DSN(dissolved in $25 \mathrm{mMTris}-\mathrm{HCl}, \mathrm{pH} 8.0 ; 50 \%$ glycerol), $0.47 \mathrm{mg} / \mathrm{ml}$ ATA, sheared dsDNA (10 copies) to improve accuracy through introduction of potential competitive binders, $10 \mathrm{nM}$ probe and RNA template was incubated in a thermal cycler at $60^{\circ} \mathrm{Cfor} 25 \mathrm{~min}$. Subsequently, $25 \mu \mathrm{L} 10 \mathrm{mMEDTA}$ was added to the reaction mixture and incubated at $60^{\circ} \mathrm{C}$ for $5 \mathrm{~min}$ to inactive DSNenzyme. The fluorescence intensity was recorded at the end of the reaction and normalized RFU were plotted against genomic equivalents of Norovirus RNA. Controls containing no template RNA were used to check for cross contamination and used to normalize the minimal background fluorescent signal.

\subsection{LARGE SCALE RNA PRODUCTION}

Additional RNA viral target was generated from a DNA template using the RiboMAXLarge Scale RNA Production System (Promega, USA). To obtain the DNA template, extracted viral 
RNA was amplified with primers flanking a 950nt genomic target (Table 2) using one step RT-PCR kit (Qiagen, USA). The total reaction mix was $25 \mu 1$ containing 50 ng RNA template and $0.6 \mu \mathrm{M}$ each forward and reverse primers. Thermal cycling was performed as follows: $30 \mathrm{~min}$ at $50^{\circ} \mathrm{C}$ for reverse transcription, $15 \mathrm{~min}$ at $95^{\circ} \mathrm{C}$ for initial PCR inactivation of the reverse transcriptase and the initial activation of the polymerase, 40 cycles of 30 seconds denaturation at $94^{\circ} \mathrm{C}, 30$ seconds annealing at $55^{\circ} \mathrm{C}$ and extension for $1 \mathrm{~min}$ at $72^{\circ} \mathrm{C}$. The $950 \mathrm{bp}$ DNA product obtained was used in a second PCR reaction to attach a T7 promoter (Table 2) on the 5 , end of the amplicon to create a linear template suitable for in-vitro transcription.

The T7 DNA template was used to create the 950ntnorovirus genome RNA replica including homologous regions for DNA probes and the primer and probe binding sites used by Hoehne et al. [73] for real time RT-PCR used for secondary detection and comparison by using the Ribo MAX Large Scale RNA Production System according to manufacturer's protocol. The obtained RNA product represents approximately $14 \%$ of the total viral genome, containing some of the secondary structures that can be expected from the native Norovirus genome.

Table 2: Primers for Large Scale RNA Production.

\begin{tabular}{llr}
\hline Primer & Sequence (5'-3') & Location* \\
\hline NVGI950-Fwd & ATGGTGATGATGAGATTGTG & $4866-4885$ \\
NVGI950-Rev & CTAACATCAGCAATCACATG & $5815-5796$ \\
NVGI950-Fwd_T7 & CAATTCCCCTCTAGTAATACGACTCACTA \\
(withT7 promoter) & TAGGGAGAATGGTGATGATGAGATTGTG \\
\hline *Genome location of primers are based on the sequence of Norwalk/68/US \\
[Gen Bank: M87661].
\end{tabular}

\subsection{VIRAL RNA EXTRACTION AND CONCENTRATION}

NorovirusGI.1RNA was kindly donated by Dr. Shay Fout (USEPA, Cincinnati, Ohio). The strain has been isolated from a human stool sample and contained $10^{6}$ virions $/ \mathrm{ml}$. Purification of viral RNA was carried out using QI Aamp Viral RNA kit (Qiagen, USA) according to manufacturer's protocol. The concentration and purity of RNA was determined using Nano Drop 1000 Spectrophotometer (Thermo Scientific, Wilmington, DE). RNA extracts were stored at $-140^{\circ} \mathrm{C}$ in the presence of $1 \mathrm{U} / \mu \mathrm{L}$ RNase inhibitor (Promega, USA).

Water samples (Little Miami River) were spikedwith live norovirus particles ranging from $10^{1}$ to $10^{4}$ copies per liter of water. Skim milk solution $(1 \%(\mathrm{w} / \mathrm{v}))$ was prepared by dissolving $1 \mathrm{~g}$ of milk powder (Difco) in $100 \mathrm{ml}$ of water and the $\mathrm{pH}$ was set to 3.5 with $1 \mathrm{~N} \mathrm{HCl}$. The spiked water samples were acidified $(\mathrm{pH}$ 3.5 ) and $10 \mathrm{ml}$ of the prepared skimmed milk solution was added to each $1 \mathrm{~L}$ sample.

The environmental water samples were then stirred for 8 hours at room temperature and flocs were allowed to settle by gravity overnight. The supernatant was decanted to avoid unsettling the sediment. The final sediment volume (approx. $100 \mathrm{ml}$ ) was centrifuged at $7000 \mathrm{~g}$ for $30 \mathrm{~min}$ at $12^{\circ} \mathrm{C}$. The supernatant was poured out and the pellet was re-suspended in 10 $\mathrm{ml}$ of $0.2 \mathrm{M}$ phosphate buffer at $\mathrm{pH} 7.5\left(1: 2, \mathrm{v} / \mathrm{v}\right.$ of $0.2 \mathrm{M} \mathrm{Na}{ }_{2} \mathrm{HPO}_{4}$ and $0.2 \mathrm{M} \mathrm{NaH} \mathrm{PO}_{4}$ ). The concentrate was used for viral RNA extraction using QIAampViral RNA kit (Qiagen, USA) according to manufacturer's protocol.

\subsection{RECOMBINANT DSN PRODUCTION IN E. COLI}

The DSN gene was synthesized by Genscript (NJ, USA) with an N-terminal 6X His tag followed by a TRX tag to facilitate disulfide bond formation. Three mutant DSN enzymes were created [1) D361N;2) D362N; and 3) D361N, D362N]via site directed mutagenesis and confirmed by Sanger sequencing. Mutant DSN enzymes were expressed in SHuffle T7 Express Competent E. coli cells (New England Biolabs, MA, USA), to enhance disulfide bond formation and proper protein folding. Shuffle cells were grown in Overnight Express at $28^{\circ} \mathrm{C}$ for 18 hours and harvested at $12,000 \mathrm{~g}$ for 20 minutes at $4^{\circ} \mathrm{C}$. All protein purification steps were done on ice. Cell pellets were lysed in $50 \mathrm{mMTris}-\mathrm{HCl}$ and $300 \mathrm{mMNaCl}, \mathrm{pH} 8.0$ using a French press and cleared by centrifugation at $30,000 \mathrm{~g}$ for 30 minutes at $4{ }^{\circ} \mathrm{C}$. Cleared lysate was applied to His60 Superflow Resin washed with 100 column volumes of a 50mMTris- $\mathrm{HCl}, 300 \mathrm{mMNaCl}$ and $20 \mathrm{mM}$ imidazole buffer, $\mathrm{pH} 8.0$ and eluted with a $50 \mathrm{mMTris}-\mathrm{HCl}$, $300 \mathrm{mMNaCl}$, and $500 \mathrm{mM}$ imidazole buffer, $\mathrm{pH}$ 8.0. Prior to use, purified enzyme fractions were incubated at $60^{\circ} \mathrm{C}$ for $15 \mathrm{~min}$ and centrifuged at $16,000 \mathrm{~g}$ to remove any non-thermostable enzymes. DSN enzymes, concentration, molecular weight and purity was verified using SDS PAGE and Bradford assays, while folding was tested via functionality for desired duplex nuclease activity.

\section{RESULTS AND DISCUSSION}

For initial experiments, synthetic oligoribonucleotides (Table 1) representing norovirus genogroup I (GI) and II (GII) in 10 -fold serial dilutions $\left(10^{0}\right.$ to $10^{4}$ oligo copies $)$ were used for assay optimization and detection of norovirus RNA was carried out by modifying a method described earlier for microRNA [17].

The oligonucleotides were designed to have an annealing temperature of $60^{\circ} \mathrm{C}$ and assays were conducted at this temperature, enabling hybridization while the probe is intact and dissociation after probe cleavage, resulting in temperature dependent fluorescent amplification of target RNA. Using the designed complimentary oligonucleotides, the fluorescent DSN assay showed variable sensitivities to the GI and GII norovirus targets (Figure 2). The optimized assay was unable to distinguish GI RNA at levels lower than $10^{2}$ genomic equivalents (Figure 2A) while GII RNA was detectable to $10^{\circ}$ genomic equivalents (Figure 2B) [46].

Due to the poor resolution observed for the lowest norovirus RNA levels and given that native DSN has limited efficacy on RNA templates longer than $21 \mathrm{nt}$, increased assay times and temperature cycling were explored to improve detection at lower levels; however, these remedies were ineffective (Figures3 and 4). 


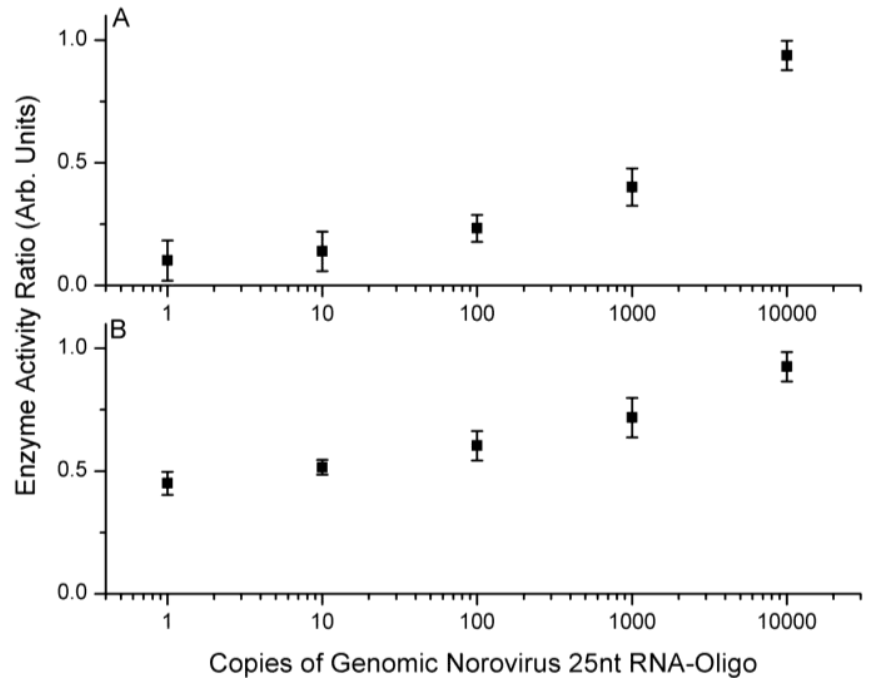

Fig. 2: Plot of Norovirus DSN assay with RNA oligos for (A) Norovirus Genogroup I and (B) Genogroup II. 10 -fold serial dilutions of RNA (10 ${ }^{4}$ to $10^{0}$ genomic equivalents per assay) were plotted versus normalized enzyme activity ratios. Enzyme activity ratios for all assays were generated by normalizing the signal relative to the minimal fluorescence generated by the zero template controls. Error bars indicate standard deviations $(\mathrm{n}=3)$.

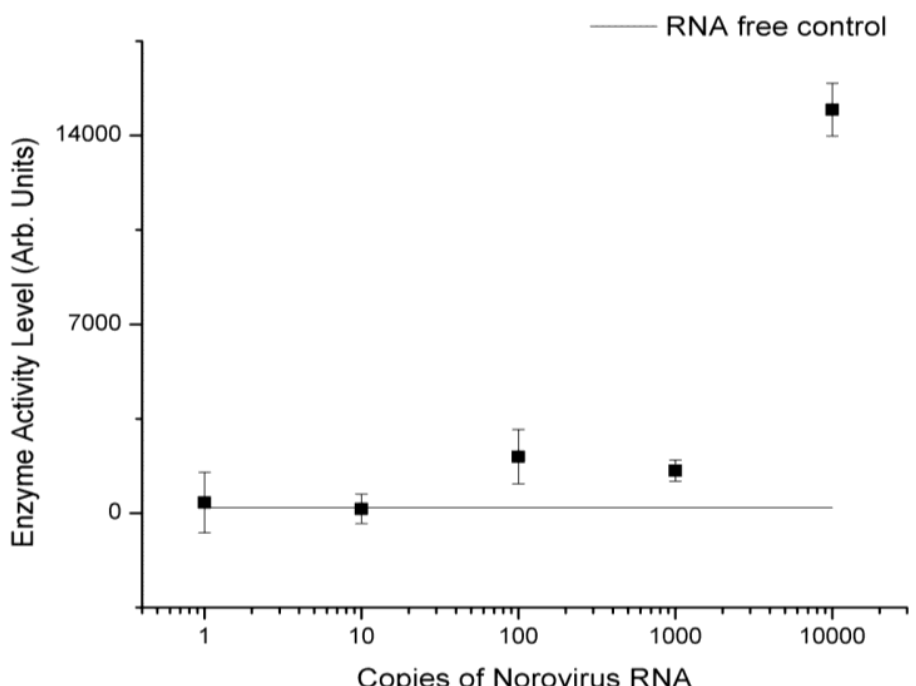

Fig. 3: DSN cycling data using G2 probe and 950bp template. DSN enzyme and the G2 probe were added to the 950nt genomic norovirus template in amounts of $10^{0}-10^{4}$ copies (Figure S1). The temperature was cycled from $50^{\circ} \mathrm{C}$ for 1 minute to $60^{\circ} \mathrm{Cfor} 1$ minute for a total of 12 cycles.

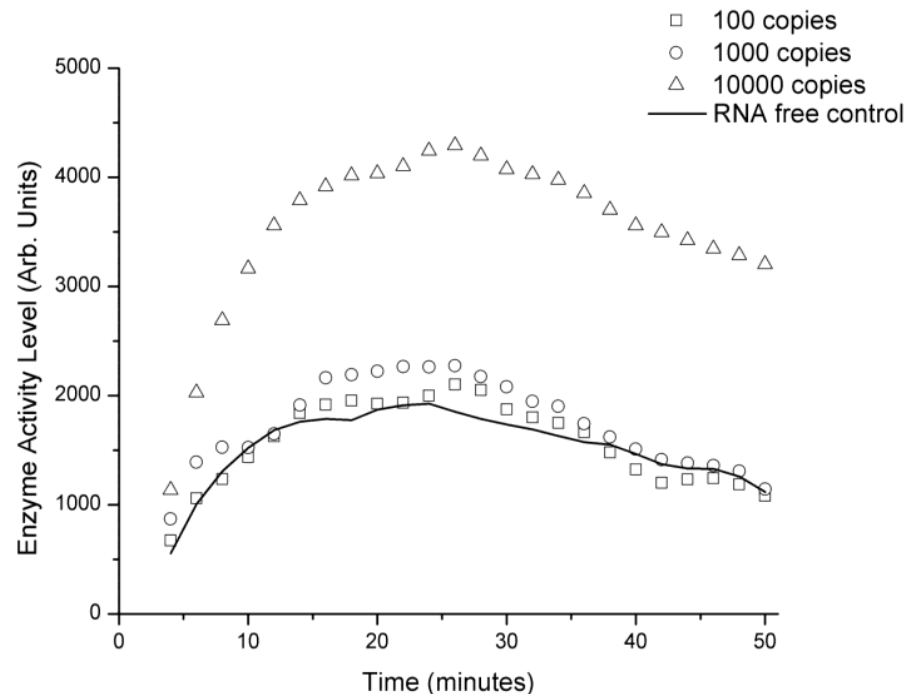

Fig. 4: Effect of longer incubation time on DSN activity using the G2 probe and the 950nt template. DSN enzyme and the G2 probe were added to the 950nt genomic norovirus template in amounts of $10^{2}-10^{4}$ copies (Figure S2). The activity of the DSN enzyme at $60^{\circ} \mathrm{Cwas}$ monitored for 50 minutes. 

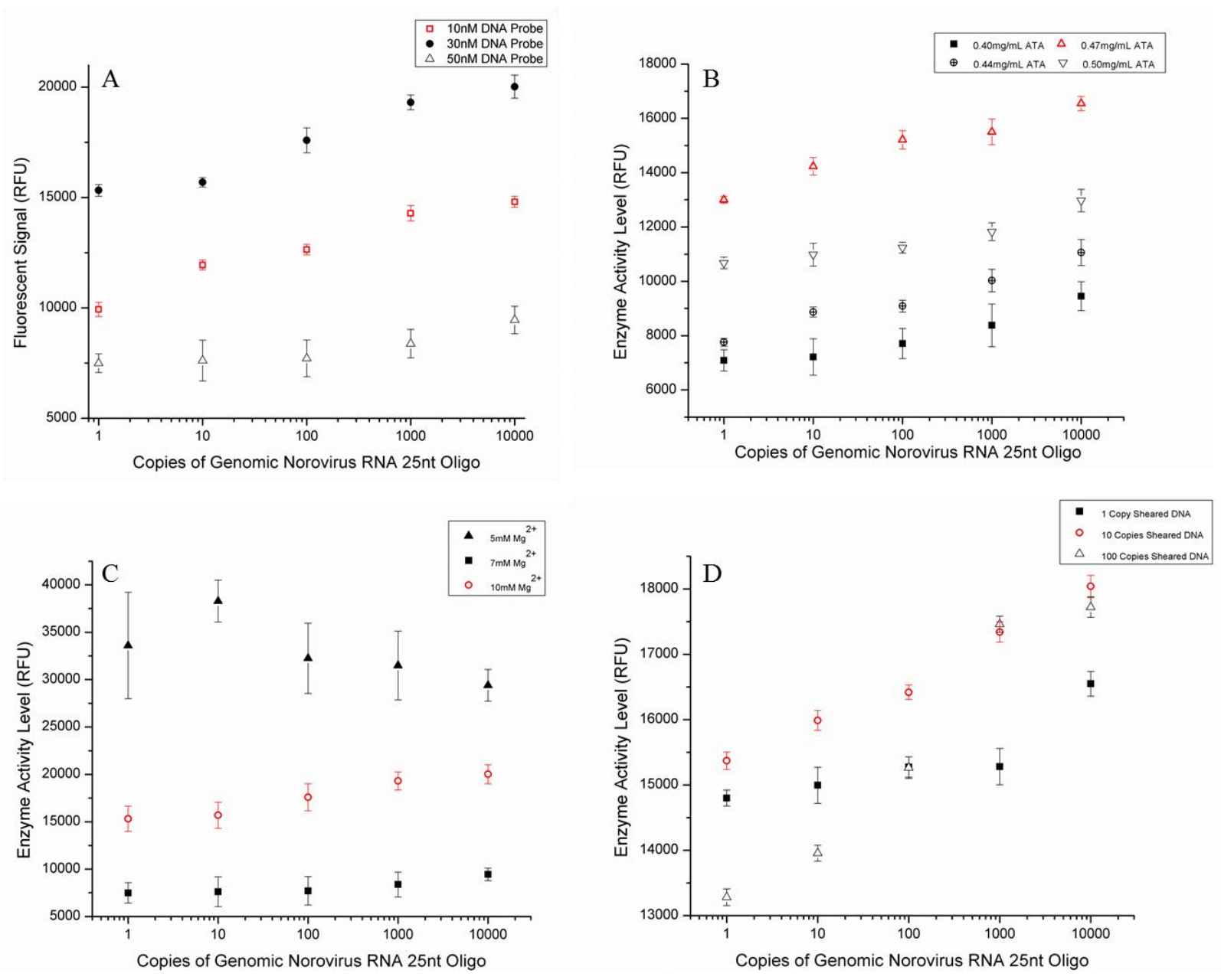

Fig. 5: A) Fluorescent signal variation (RFU) as a function of 25nt RNA copies for varying DNA probe concentrations. Error bars depict standard deviation $(n=3)$.B)Scatter plot of relative fluorescence units (RFU) as a function of Norovirus RNA copies for different concentrations of ATA. All error bars refer to standard deviation $(n=3)$. C) Scatter plot of normalized enzyme activity level (RFU) as a function of Norovirus RNA $25 n t$ oligo copies for varying Mg ${ }^{2+}$ concentration. Error bars depict standard deviation $(n=3)$.D)Scatter plot of relative fluorescence units (RFU) as a function of Norovirus RNA copies for varying sheared DNA copies. Error bars depict standard deviation $(n=3)$.

Assay specificity was further explored by varying concentrations of the single stranded DNA probe to reduce fluorescent signal generated by nonspecific probe cleavage. All probe concentrations tested, $10 \mathrm{nM}, 30 \mathrm{nM}$ and $50 \mathrm{nM}$, produced consistent results at varying copy numbers of the Norovirus RNA oligos (Figure 5A). A probe concentration of $10 \mathrm{nM}$ was chosen for future experimentation due to its superior sensitivity to varying RNA oligo copy numbers.

Further optimization efforts were undertaken using aurintricarboxylicacid (ATA) and $\mathrm{Mg}^{2+}$. ATA was chosen due to its favorable binding outcomes to DD residues, a motif which forms the catalytic center for RNA polymerases and integrases $[74,75]$ and occurs three times within the DSN amino acid sequence [76]. It was found that $0.47 \mathrm{mg} / \mathrm{mL}$ ATA provided optimum sensitivity for the fluorescent DSN assay (Figure 5B).

The effect of additional $\mathrm{Mg}^{2+}$ in the assay was also examined, given that DSN as well as many other enzymes that act on phosphate containing substrates require magnesium ion for their activity. The impact of varying $\mathrm{Mg}^{2+}$ concentration on DSN activity has been well documented [15]. Maximum DSN digestion activity is reached at $\sim 20 \mathrm{mM} \mathrm{Mg}^{2+}$ and begins to reduce beyond this concentration [15]. Notably, increasing the amount of $\mathrm{Mg}^{2+}$ in the reaction mix aided in improving the efficiency of detection in the presence of ATA, and a total $\mathrm{Mg}^{2+}$ concentration of $10 \mathrm{mM}$ provided superior sensitivity for our norovirus assay (Figure 5C).

The final assay optimization investigated the effects of adding sheared dsDNA to our DSN assay. It has been reported that DSN can demonstrate minor activity against single stranded DNA when both DSN enzyme and substrate (DNA-RNA duplex) are present in high concentrations [27]. This activity, however, is not evident in the presence of competitive dsDNA [27]. Therefore, sheared dsDNA was added to the fluorescent DSN assay to minimize cleavage of unbound ssDNA probe, resulting in nonspecific fluorescent signal. It was found that 10 sheared copies of a $1 \mathrm{~kb}$ DNA sequence resulted in the most consistent results for discrimination between samples (Figure 5D).

After this optimization, we sought to test our improved method on longer RNA targets. We chose a 950nt portion of the 
norovirus genome to test the effects of secondary structure on the DSN assay, since this provides a more realistic target size while minimizing exposure to the full virus. The sequence corresponding to norovirus GI was chosen due to its prevalence in waters around Cincinnati. The RNA product contains approximately $14 \%$ of the total viral genome, and includes homologous regions for DNA Taqmanprobes used for our initial DSN assay, as well as the primer and probe RT-qPCR binding sites used by Hoehne et al. [73]. Through the addition of ATA, $\mathrm{Mg}^{2+}$ and sheared dsDNA, increased separation for lower norovirus copy numbers was achieved (Figure 6).

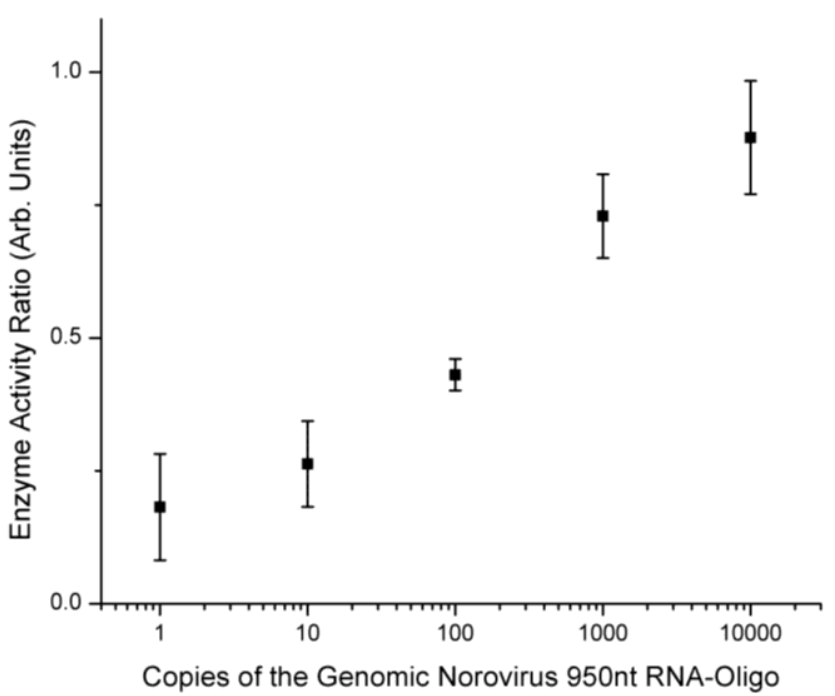

Fig. 6: Plot of Norovirus DSN assay with 950nt fragments of Norovirus RNA.10-fold serial dilutions $\left(10^{0}\right.$ to $10^{4}$ genomic equivalents per assay) of Norovirus GI RNA were plotted versus normalized enzyme activity ratios. Enzyme activity ratios were generated by normalizing the signal relative to the minimal fluorescence generated by the zero template controls. Error bars indicate standard deviations $(\mathrm{n}=3)$.

In order to verify the efficacy of the optimized assay we performed an experiment spiking environmental water with norovirus particles $\left(10^{0}-10^{4}\right.$ particles per liter of water) and extracted the total RNA to mimic a real world testing scenario. In this way the performance of DSN could be evaluated in RNAwater extracts replete with non-target RNA and natural inhibitors which co-elute with the extraction (Figure 7). Performed as a blind test, the concentration of norovirus particles was correctly identified in $89 \%$ of the trials with no false positives. RT-qPCR, using the primers and probe developed previously [73], was used as a comparison to test the accuracy of ourDSN based quantification method (Figure 8). Larger variation in the $\mathrm{C}_{\mathrm{t}}$ values of the RT-qPCR assay were observed (Figures 7 and 8), indicating the higher sensitivity of the DSN assay for the same RNA samples under our operating conditions. Recently, advanced PCR techniques such as digital PCR have been described for absolute RNA quantification [77], but the high equipment cost and time limits the applicability of such techniques. The total reaction time for the presented DSN strategy is less than 30 minutes, compared to the several hours required for RT-qPCR [78], and can be achieved on a simple heat block, rather than a more costly thermocycler.

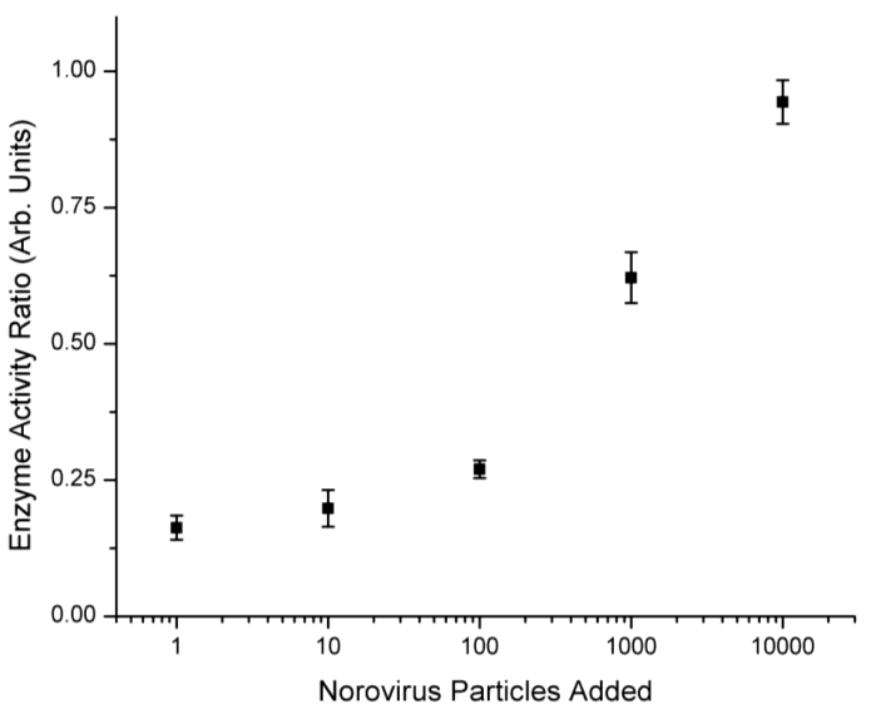

Fig. 7: Plot of Norovirus DSN assay with RNA extracted from water spiked with norovirus particles. 10 -fold serial dilutions of RNA $\left(10^{0}\right.$ to $10^{4}$ genomic equivalents per assay) of Norovirus GI were plotted versus normalized enzyme activity ratios. Enzyme activity ratios were generated by normalizing the signal relative to the minimal fluorescence generated by the zero template controls. Error bars indicate standard deviation $(\mathrm{n}=3)$.

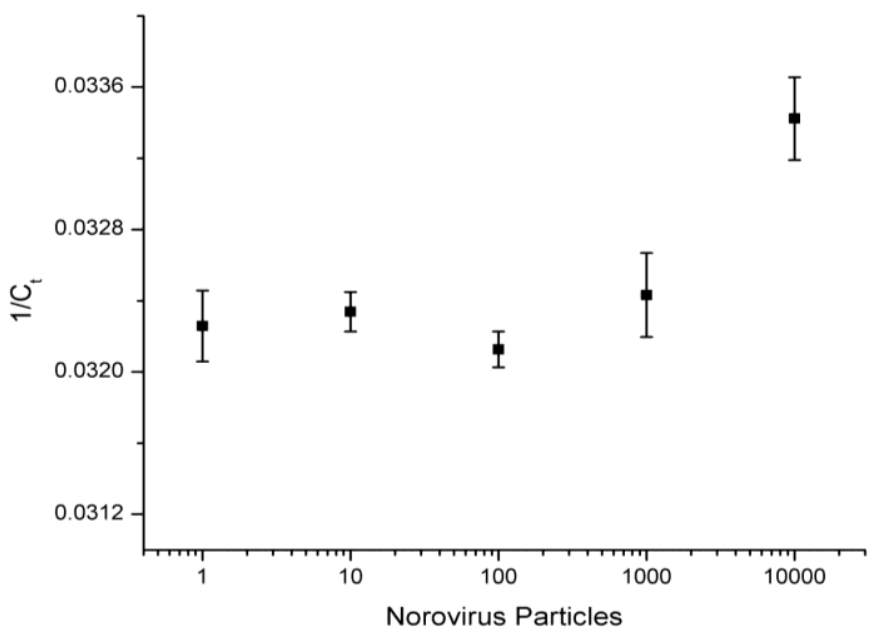

Fig. 8: Plot of norovirus RT-qPCR with RNA extracted from environmental water spiked with norovirus particles. 10 -fold serial dilutions of RNA $\left(10^{0}\right.$ to $10^{4}$ genomic equivalents per assay) of Norovirus GI were plotted versus $1 / \mathrm{C}_{t}$ value. All error bars indicate standard deviations $(n=3)$.

The assay was independently verified in the lab of Dr. Shay Fout, USEPA, Cincinnati, Ohio (Figure 9). The lower limit of detection was found to be 10 copies per assay, below the minimum concentration required for infection (18 viral copies) $[46,79,80]$. While variation was seen in independent testing for samples containing $10^{3}$ copies, a reliable separation between 10 
and 100 virions was observed, with the most significant signal separation between $10^{3}$ and $10^{4}$ viral particles.

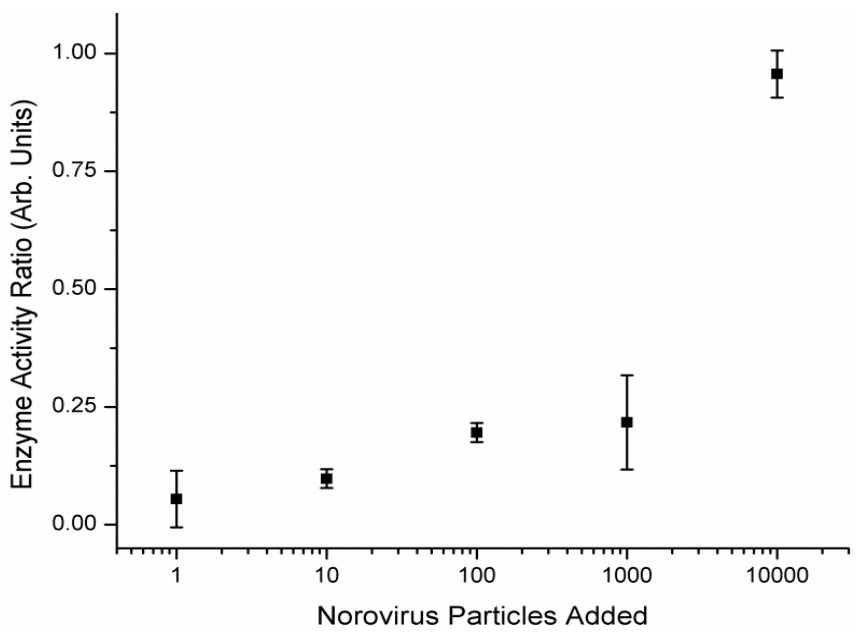

Fig. 9: Plot of results obtained through independent verification of the DSN assay at the USEPA. 10-fold serial dilutions of RNA (100 to 104 genomic equivalents per assay) of Norovirus GI.Enzyme activity ratios were generated by normalizing the signal relative to the minimal fluorescence generated by the zero template controls. Error bars represent the standard deviation $(n=3)$.

\subsection{Rational Design of DSN Mutants}

To engineer the desired enzyme function without the necessity of ATA or other additives, the 3rd DD site (green/red in Figure 10), corresponding to amino acids 361-362, was chosen as the target for mutagenesis. This cluster was chosen because of the classic helix-turn-helix motif (right, Figure 10) in the predicted structure, which is a common DNA interacting domain [81-85]. While both helixes contain DD sites, the shorter of the two was chosen for the D to $\mathrm{N}$ mutations, since the longer "recognition" helix is often the DNA interacting domain [86, 87]. The Asp amino acids were specifically targeted based on the previous theoretical work with ATA, as well as evidence that these amino acids complex with $\mathrm{Ca}^{2+}$, to mediate phosphate interactions of the nucleic acid backbone [86, 87]. Three separate mutants, D362N, D361N, and D361N D362N, along with an unmutated version (DD), were produced in E. coli and screened for nuclease activity using the optimized conditions developed for the commercial enzyme. Enzyme activity ratios for all mutants were determined by normalizing the minimal fluorescent background signal generated by the zero template controls and obtaining the ratio of signal generated in the absence of ATA to the signal generated in the presence of ATA. All enzymes produced in E. coli retained some nuclease activity; however, D361N was found to be the most effective variant, demonstrating selective DNA nuclease activity in the absence of ATA for both the 950nt RNA target (Figure 11) and the shorter $25 \mathrm{nt}$ RNA oligos used at $10^{4}$ copies (Figure 11 ). The high enzyme activity ratios (all $>4$ ) indicate improved activity in the absence of ATA, in some cases over 180x greater for the D361N mutant. Surprisingly, the unmutated DD enzyme produced in $E$. coli also showed improved activity in the absence of ATA, unlike the commercial DSN enzyme. Since norovirus cannot be synthesized via cell culture, and must be purified from the feces of an infected mammalian host, obtaining sufficient quantities of norovirus source material is a challenge, limiting our mutant DSN experiments to synthetic RNA targets.

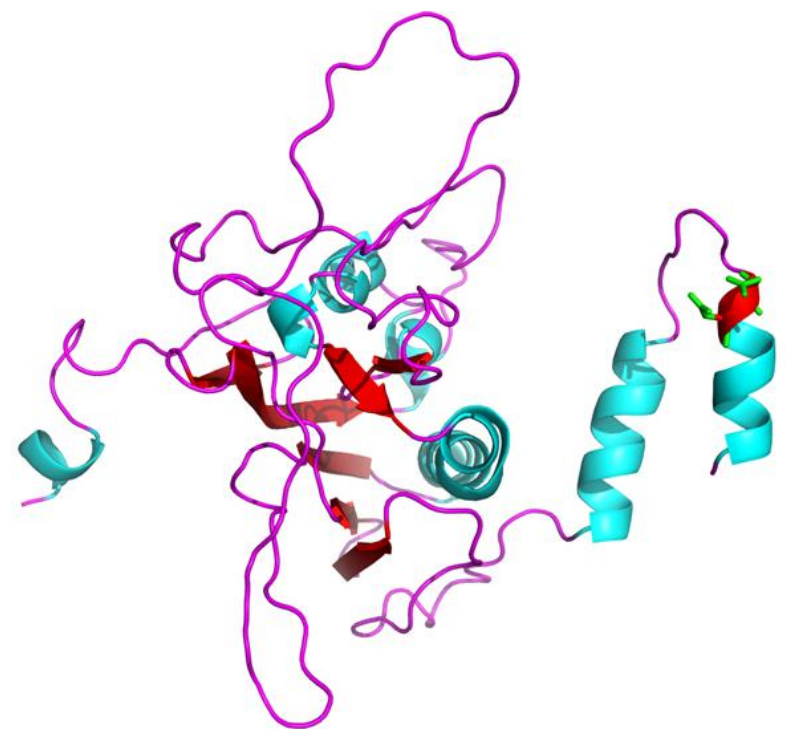

Fig. 10: Predicted crystal structure of DSN, generated using PyMOL and ITASSER [88-90]. D amino acid mutation sites are highlighted in green.

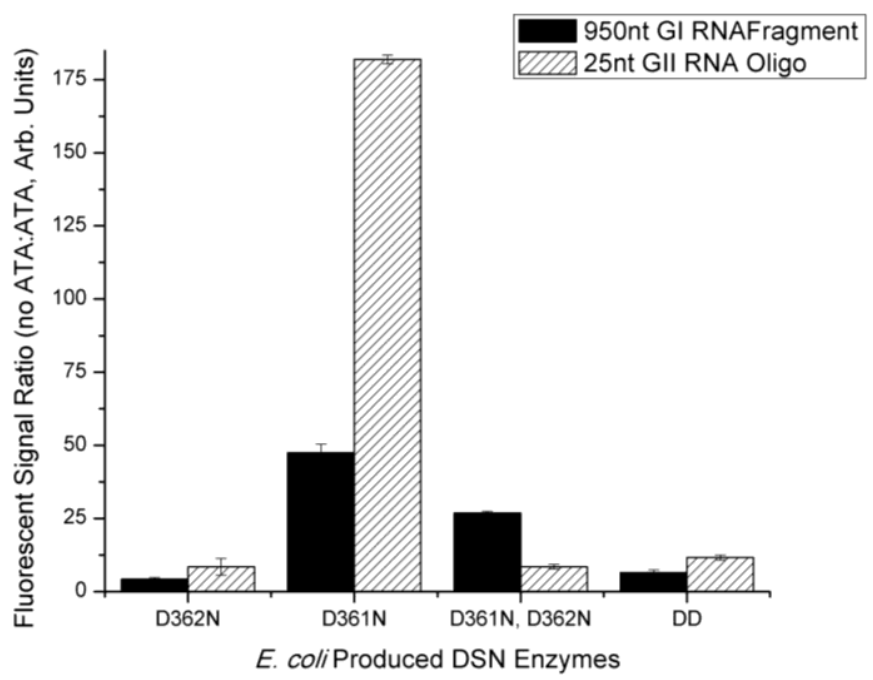

Fig. 11: Fluorescent signal ratios for equimolar DSN concentrations in the presence and absence of the ATA inhibitor for A) the 950nt Norovirus genomic fragment and B) the GII RNA oligo.The fluorescent signal ratio was calculated using the ratio of the signal of the non-ATA containing reaction to the reaction containing ATA after normalizing to the zero template controls. Both RNA templates were used at copies. Error bars represent the standard deviation of at least 3 samples.

\section{ACKNOWLEDGEMENTS}

This work was supported by NSF grants CBET-1509022 and EEC-1404766. The authors would like to thank Dr. Shay Fout for independent assay tests and assistance with Norovirus particles. We also thank E. Carlson and E. Ruder for their laboratory assistance with mutant DSN enzymes. 


\section{CONCLUSIONS}

The advantage of targeting viral RNA directly provides the opportunity to extend our system to other RNA pathogens such as Influenza, Ebolavirus, Zika, Hepatitis, and Chandipura viruses. Furthermore, DSN has been largely limited to short RNA targets, thus the optimization of our reaction with the use of ATA was important for enabling longer targets. The optimization with ATA ensured specific hybridization of the probes to the long RNA targets and enabled the rational design of DSN mutants that allow for duplex-specific nuclease activity on longer RNA targets. Future work will explore improved DSN mutants beyond the limited number of preliminary mutations to further increase enzyme functionality.

The described method has the opportunity to surpass RTqPCR as a faster, more cost effective RNA detection scheme and, when multiplexed with different colored Taqman probes, a more versatile approach. The isothermal RNA assay we have developed will find utility where thermocyclers are either too costly or unavailable, enabling future low cost RNA and viral detection sensors.

\section{Financial support and sponsorship: Nil.}

Conflict of Interests: There are no conflicts of interest.

\section{REFERENCES}

1. D. R. Walt. Miniature Analytical Methods for Medical Diagnostics. Science. 2005; 308(5719): 217-219.

2. D. A. Relman. The search for unrecognized pathogens. Science. 1999; 284(5418): 1308-1310.

3. J. Lamb, E. D. Crawford, D. Peck, J. W. Modell, I. C. Blat, M. J. Wrobel, J. Lerner, J.-P. Brunet, A. Subramanian, K. N. Ross, M. Reich, H. Hieronymus, G. Wei, S. A. Armstrong, S. J. Haggarty, P. A. Clemons, R. Wei, S. A. Carr, E. S. Lander,T. R. Golub. The Connectivity Map: Using Gene-Expression Signatures to Connect Small Molecules, Genes, and Disease. Science. 2006; 313(5795): 1929-1935.

4. J. Drews. Drug Discovery: A Historical Perspective. Science. 2000; 287(5460): 1960-1964.

5. E. DeLong, G. Wickham,N. Pace. Phylogenetic stains: ribosomal RNA-based probes for the identification of single cells. Science. 1989; 243(4896): 1360-1363.

6. M. Mandal,R. R. Breaker. Gene regulation by riboswitches. Nat Rev Mol Cell Biol. 2004; 5(6): 451-463.

7. J. Compton. Nucleic acid sequence-based amplification. Nature. 1991; 350(6313): 91-92.

8. Mader, U. Riehle, T. Brandstetter, E. Stickeler, A. zur Hausen,J. Rühe. Microarray-based amplification and detection of RNA by nucleic acid sequence based amplification. Analytical and Bioanalytical Chemistry. 2010; 397(8): 3533-3541.

9. Heim, I. M. Grumbach, S. Zeuke,B. Top. Highly sensitive detection of gene expression of an intronless gene: amplification of mRNA, but not genomic DNA by nucleic acid sequence based amplification (NASBA). Nucleic Acids Research. 1998; 26(9): 2250-2251.

10. Lagunavicius, E. Merkiene, Z. Kiveryte, A. Savaneviciute, V. Zimbaite-Ruskuliene, T. Radzvilavicius,A. Janulaitis. Novel application of Phi29 DNA polymerase: RNA detection and analysis in vitro and in situ by target RNA-primed RCA. RNA. 2009; 15(5): 765-771.
11. E. Merkiene, E. Gaidamaviciute, L. Riauba, A. Janulaitis,A. Lagunavicius. Direct detection of RNA in vitro and in situ by targetprimed RCA: The impact of E. coli RNase III on the detection efficiency of RNA sequences distanced far from the 3'-end. RNA. 2010; 16(8): 1508-1515.

12. T. Notomi, H. Okayama, H. Masubuchi, T. Yonekawa, K. Watanabe, N. Amino,T. Hase. Loop-mediated isothermal amplification of DNA. Nucleic Acids Research. 2000; 28(12): e63-e63.

13. T. C. Cardoso, H. F. Ferrari, L. C. Bregano, C. Silva-Frade, A. C. G. Rosa,A. L. Andrade. Visual detection of turkey coronavirus RNA in tissues and feces by reverse-transcription loop-mediated isothermal amplification (RT-LAMP) with hydroxynaphthol blue dye. Molecular and Cellular Probes. 2010; 24(6): 415-417.

14. Y. Zhao, L. Zhou,Z. Tang. Cleavage-based signal amplification of RNA. Nat Commun. 2013; 4(1493.

15. V. E. Anisimova, D. V. Rebrikov, D. A. Shagin, V. B. Kozhemyako, N. I. Menzorova, D. B. Staroverov, R. Ziganshin, L. L. Vagner, V. A. Rasskazov, S. A. Lukyanov,A. S. Shcheglov. Isolation, characterization and molecular cloning of duplex-specific nuclease from the hepatopancreas of the Kamchatka crab. BMC Biochem. 2008; $9(14$.

16. D. A. Shagin, D. V. Rebrikov, V. B. Kozhemyako, I. M. Altshuler, A. S. Shcheglov, P. A. Zhulidov, E. A. Bogdanova, D. B. Staroverov, V. A. Rasskazov,S. Lukyanov. A novel method for SNP detection using a new duplex-specific nuclease from crab hepatopancreas. Genome Res. 2002; 12(12): 1935-1942.

17. B.-C. Yin, Y.-Q. Liu,B.-C. Ye. One-Step, Multiplexed Fluorescence Detection of microRNAs Based on Duplex-Specific Nuclease Signal Amplification. Journal of the American Chemical Society. 2012; 134(11): 5064-5067.

18. P. A. Zhulidov, E. A. Bogdanova, A. S. Shcheglov, L. L. Vagner, G. L. Khaspekov, V. B. Kozhemyako, M. V. Matz, E. Meleshkevitch, L. L. Moroz, S. A. Lukyanov,D. A. Shagin. Simple cDNA normalization using kamchatka crab duplex-specific nuclease. Nucleic Acids Research. 2004; 32(3): e37-e37.

19. E. A. Bogdanova, E. V. Barsova, I. A. Shagina, A. Scheglov, V. Anisimova, L. L. Vagner, S. A. Lukyanov,D. A. Shagin. Normalization of full-length-enriched cDNA. Methods Mol Biol. 2011; 729(85-98.

20. D. C. Christodoulou, J. M. Gorham, D. S. Herman,J. G. Seidman. Construction of normalized RNA-seq libraries for next-generation sequencing using the crab duplex-specific nuclease. Curr Protoc Mol Biol. 2011; Chapter 4(Unit4 12.

21. Shagina, E. Bogdanova, I. Z. Mamedov, Y. Lebedev, S. Lukyanov,D. Shagin. Normalization of genomic DNA using duplex-specific nuclease. Biotechniques. 2010; 48(6): 455-459.

22. E. A. Bogdanova, I. A. Shagina, E. Mudrik, I. Ivanov, P. Amon, L. L. Vagner, S. A. Lukyanov,D. A. Shagin. DSN depletion is a simple method to remove selected transcripts from cDNA populations. Molecular Biotechnology. 2009; 41(3): 247-253.

23. E. A. Bogdanova, I. A. Shagina, Y. G. Yanushevich, L. L. Vagner, S. A. Lukyanov,D. A. Shagin. Preparation of prokaryotic cDNA for full-scale transcriptome analysis. Russian Journal of Bioorganic Chemistry. 2011; 37(6): 775-778.

24. H. Yi, Y. J. Cho, S. Won, J. E. Lee, H. Jin Yu, S. Kim, G. P. Schroth, S. Luo,J. Chun. Duplex-specific nuclease efficiently removes rRNA for prokaryotic RNA-seq. Nucleic Acids Res. 2011; 39(20): e140.

25. R. H. Peng, A. S. Xiong, Y. Xue, X. Li, J. G. Liu, B. Cai,Q. H. Yao. Kamchatka crab duplex-specific nuclease-mediated transcriptome subtraction method for identifying long cDNAs of differentially expressed genes. Anal Biochem. 2008; 372(2): 148-155.

26. F. Swennenhuis, B. Foulk, F. A. W. Coumans,L. W. M. M. Terstappen. Construction of repeat-free fluorescence in situ hybridization probes. Nucleic Acids Research. 2012; 40(3): e20e20.

27. Y. Zhao, H. Hoshiyama, J. W. Shay,W. E. Wright. Quantitative telomeric overhang determination using a double-strand specific nuclease. Nucleic Acids Research. 2008; 36(3): e14-e14. 
28. Y. Zhao, J. W. Shay,W. E. Wright. Telomere G-overhang length measurement method 1: the DSN method. Methods Mol Biol. 2011; 735(47-54.

29. M. Liu, M. Yuan, X. Lou, H. Mao, D. Zheng, R. Zou, N. Zou, X. Tang,J. Zhao. Label-free optical detection of single-base mismatches by the combination of nuclease and gold nanoparticles. Biosens Bioelectron. 2011; 26(11): 4294-4300.

30. Z. Kapikian, R. G. Wyatt, R. Dolin, T. S. Thornhill, A. R. Kalica,R. M. Chanock. Visualization by Immune Electron Microscopy of a 27nm Particle Associated with Acute Infectious Nonbacterial Gastroenteritis. Journal of Virology. 1972; 10(5): 1075-1081.

31. P. R. Lambden, E. O. Caul, C. R. Ashley,I. N. Clarke. Sequence and genome organization of a human small round-structured (Norwalklike) virus. Science. 1993; 259(5094): 516-519.

32. P. R. Lambden, B. Liu,I. N. Clarke. A conserved sequence motif at the 5 ' terminus of the Southampton virus genome is characteristic of the Caliciviridae. Virus Genes. 1995; 10(2): 149-152.

33. X. Jiang, M. Wang, K. Wang,M. K. Estes. Sequence and genomic organization of Norwalk virus. Virology. 1993; 195(1): 51-61.

34. N. Xi, D. Y. Graham, K. N. Wang,M. K. Estes. Norwalk virus genome cloning and characterization. Science. 1990; 250(4987): 1580-1583.

35. R. L. Fankhauser, S. S. Monroe, J. S. Noel, C. D. Humphrey, J. S. Bresee, U. D. Parashar, T. Ando,R. I. Glass. Epidemiologic and molecular trends of "Norwalk-like viruses" associated with outbreaks of gastroenteritis in the United States. J Infect Dis. 2002; 186(1): 17.

36. S. M. Green, P. R. Lambden, E. O. Caul, C. R. Ashley,I. N. Clarke. Capsid diversity in small round-structured viruses: molecular characterization of an antigenically distinct human enteric calicivirus. Virus Res. 1995; 37(3): 271-283.

37. S. M. Karst, C. E. Wobus, M. Lay, J. Davidson,H. W. t. Virgin. STAT1-dependent innate immunity to a Norwalk-like virus. Science. 2003; 299(5612): 1575-1578.

38. S. L. Oliver, A. M. Dastjerdi, S. Wong, L. El-Attar, C. Gallimore, D. W. Brown, J. Green,J. C. Bridger. Molecular characterization of bovine enteric caliciviruses: a distinct third genogroup of noroviruses (Norwalk-like viruses) unlikely to be of risk to humans. J Virol. 2003; 77(4): 2789-2798.

39. J. Vinje,M. P. Koopmans. Simultaneous detection and genotyping of "Norwalk-like viruses" by oligonucleotide array in a reverse line blot hybridization format. J Clin Microbiol. 2000; 38(7): 2595-2601.

40. de Wit, M. P. Koopmans, L. M. Kortbeek, W. J. Wannet, J. Vinje, F. van Leusden, A. I. Bartelds,Y. T. van Duynhoven. Sensor, a population-based cohort study on gastroenteritis in the Netherlands: incidence and etiology. Am J Epidemiol. 2001; 154(7): 666-674.

41. E. Scallan, R. M. Hoekstra, F. J. Angulo, R. V. Tauxe, M. A. Widdowson, S. L. Roy, J. L. Jones,P. M. Griffin. Foodborne illness acquired in the United States--major pathogens. Emerg Infect Dis. 2011; 17(1): 7-15.

42. M. Patel, M. A. Widdowson, R. I. Glass, K. Akazawa, J. Vinje,U. D. Parashar. Systematic literature review of role of noroviruses in sporadic gastroenteritis. Emerg Infect Dis. 2008; 14(8): 1224-1231.

43. O'Ryan, M. Riera-Montes, B. Lopman. Norovirus in Latin America: Systematic Review and Meta-Analysis. Pediatr Infect Dis J. 2016; Published Ahead of Print.

44. K. Pringle, B. Lopman, E. Vega, J. Vinje, U. Parashar, A. Hall. Noroviruses: epidemiology, immunity and prospects for prevention. Future Microbiology. 2015; 10(1): 53-67.

45. F. Kowalzik, M. Riera-Montes, T. Verstraeten, F. Zepp. The Burden of Norovirus Disease in Children in the European Union. 2015. 34(3): 229-234

46. J. Mans, G. E. Armah, A. D. Steele, M. B. Taylor. Norovirus Epidemiology in Africa: A Review. PLoS ONE, 2016; 11(4): e0146280.

47. S. M. Ahmed, A. J. Hall, A. E. Robinson, L. Verhoef, P. Premkumar, U. D. Parashar, M. Koopmans,B. A. Lopman. Global prevalence of norovirus in cases of gastroenteritis: a systematic review and metaanalysis. The Lancet Infectious Diseases. 2014; 14(8): 725-730.
48. Lopman, A. J. Hall, A. T. Curns,U. D. Parashar. Increasing rates of gastroenteritis hospital discharges in US adults and the contribution of norovirus, 1996-2007. Clin Infect Dis. 2011; 52(4): 466-474.

49. J. Hall, A. T. Curns, L. C. McDonald, U. D. Parashar,B. A. Lopman. The roles of Clostridium difficile and norovirus among gastroenteritis-associated deaths in the United States, 1999-2007. Clin Infect Dis. 2012; 55(2): 216-223.

50. F. Teunis, C. L. Moe, P. Liu, S. E. Miller, L. Lindesmith, R. S. Baric, J. Le Pendu,R. L. Calderon. Norwalk virus: how infectious is it? J Med Virol. 2008; 80(8): 1468-1476.

51. T. Halperin, M. Yavzori, A. Amitai, E. Klement, R. Kayouf, I. Grotto, M. Huerta, L. A. Hadley, S. S. Monroe, D. Cohen,N. Orr. Molecular analysis of noroviruses involved in acute gastroenteritis outbreaks in military units in Israel, 1999-2004. Eur J Clin Microbiol Infect Dis. 2005; 24(10): 697-700.

52. E. L. Yee, H. Palacio, R. L. Atmar, U. Shah, C. Kilborn, M. Faul, T. E. Gavagan, R. D. Feigin, J. Versalovic, F. H. Neill, A. L. Panlilio, M. Miller, J. Spahr,R. I. Glass. Widespread outbreak of norovirus gastroenteritis among evacuees of Hurricane Katrina residing in a large "megashelter" in Houston, Texas: lessons learned for prevention. Clin Infect Dis. 2007; 44(8): 1032-1039.

53. L. Verhoef, E. Depoortere, I. Boxman, E. Duizer, Y. van Duynhoven, J. Harris, C. Johnsen, A. Kroneman, S. Le Guyader, W. Lim, L. Maunula, H. Meldal, R. Ratcliff, G. Reuter, E. Schreier, J. Siebenga, K. Vainio, C. Varela, H. Vennema,M. Koopmans. Emergence of New Norovirus Variants on Spring Cruise Ships and Prediction of Winter Epidemics. Emerging Infectious Disease journal. 2008; 14(2): 238 .

54. S. R. Seitz, J. S. Leon, K. J. Schwab, G. M. Lyon, M. Dowd, M. McDaniels, G. Abdulhafid, M. L. Fernandez, L. C. Lindesmith, R. S. Baric,C. L. Moe. Norovirus Infectivity in Humans and Persistence in Water. Applied and Environmental Microbiology. 2011; 77(19): 6884-6888.

55. J. L. Hyde, S. V. Sosnovtsev, K. Y. Green, C. Wobus, H. W. Virgin,J. M. Mackenzie. Mouse norovirus replication is associated with virus-induced vesicle clusters originating from membranes derived from the secretory pathway. J Virol. 2009; 83(19): 97099719.

56. S. Taube, A. Kolawole, M. Höhne, J. Wilkinson, S. Handley, J. Perry, L. Thackray, R. Akkina, C.Wobus.A Mouse Model for Human Norovirus.mBio. 2013; 4(4): e00450-13

57. Khamrin, A. Thongprachum, S. Okitsu, N. Maneekarn, S. Hayakawa,H. Ushijima. Comparison of three rapid tests for detection of norovirus in stool samples of acute gastroenteritis pediatric patients. Journal of Tropical Pediatrics. 2014; 60(6): 481483.

58. Derrington, F. Moore, D. Thorley,T. Constantino. Evaluation of Immunochromatographic Test Kits For the Detection of Norovirus in Faecal Specimens. Pathology - Journal of the RCPA. 2014; 46(S100).

59. L. Atmar,M. K. Estes. Diagnosis of noncultivatable gastroenteritis viruses, the human caliciviruses. Clin Microbiol Rev. 2001; 14(1): 15-37.

60. M. S. Plantenga, B. Shiferaw, W. E. Keene, C. Biggs, J. M. Terry, L. Grenz,P. R. Cieslak. Specimen Collection and Confirmation of Norovirus Outbreaks. Emerging Infectious Diseases. 2011; 17(8): 1553-1555.

61. H. C. P. Santos, L. C. Turones, F. S. Fiaccadori, D. d. D. de Paula Cardoso,M. B. de Lima Dias. Screening of Fecal Samples From Asymptomatic Children, For Norovirus Detection, Using a Third Generation Enzyme Immunoassay Commercial Kit. Revista de Patologia Tropical. 2014; 43(2): 143-149.

62. G. Lennon, N. Reidy, P. J. Collins, L. Gunn, P. V. Coyle, B. Cryan, S. Fanning,H. O'Shea. A comparison of the efficiency of ELISA and selected primer sets to detect Norovirus isolates in southern Ireland over a four-year period (2002-2006): variation in detection rates and evidence for continuing predominance of NoV GII.4 genotype. Archives of Virology. 2014; 159(7): 1697-1705. 
63. F.-R. Lin, Y.-H. Shen, C.-W. Fang, S.-S. Shie, C.-G. Huang, S. Yang, S.-L. Yang, K.-C. Tsao, Y.-C. Huang, M.-W. Lai,C.-J. Chen. Incidence of and Factors Associated with False Positives in Laboratory Diagnosis of Norovirus Infection by Amplification of the RNA-Dependent RNA Polymerase Gene. PLoS ONE. 2014; 9(9): e109876.

64. N. L. Dunbar, L. D. Bruggink,J. A. Marshall. Evaluation of the RIDAGENE real-time PCR assay for the detection of GI and GII norovirus. Diagn Microbiol Infect Dis. 2014; 79(3): 317-321.

65. K. Ambert-Balay, P. Pothier. Evaluation of 4 immunochromatographic tests for rapid detection of norovirus in faecal samples. Journal of Clinical Virology. 2013; 56(3): 278-282.

66. V. Costantini, L. Grenz, A. Fritzinger, D. Lewis, C. Biggs, A. Hale,J. Vinjé. Diagnostic Accuracy and Analytical Sensitivity of IDEIA Norovirus Assay for Routine Screening of Human Norovirus. Journal of Clinical Microbiology. 2010; 48(8): 2770-2778.

67. N. Shigemoto, Y. Tanizawa, T. Matsuo, N. Sakamaki, Y. Ohiro, S. Takayasu,S. Fukuda. Clinical evaluation of a bioluminescent enzyme immunoassay for detecting norovirus in fecal specimens from patients with acute gastroenteritis. Journal of Medical Virology. 2014; 86(7): 1219-1225.

68. K. Hanaki, F. Ike, A. Kajita, W. Yasuno, M. Yanagiba, M. Goto, K. Sakai, Y. Ami,S. Kyuwa. Detection of murine norovirus by reverse transcription loop-mediated isothermal amplification. J Virol Methods. 2014; 204(17-24.

69. J. Luo, Z. Xu, K. Nie, X. Ding, L. Guan, J. Wang, Y. Xian, X. Wu,X. Ma. Visual detection of norovirus genogroup II by reverse transcription loop-mediated isothermal amplification with hydroxynaphthol blue dye. Food Environ Virol. 2014; 6(3): 196201.

70. Hong, J. Kwon, D. Kim,S. Yang. A rapid, sensitive and selective electrochemical biosensor with concanavalin A for the preemptive detection of norovirus. Biosensors and Bioelectronics. 2015; 64(0): 338-344.

71. J. Pratt, I.J. MacRae. The RNA-induced Silencing Complex: A Versatile Gene-silencing Machine. Journal of Biological Chemistry. 2009; 284(27): 17897-17901.

72. L. Hofacker, W. Fontana, P. F. Stadler, L. S. Bonhoeffer, M. Tacker,P. Schuster. Fast folding and comparison of RNA secondary structures. Monatshefte für Chemie / Chemical Monthly. 1994; 125(2): 167-188.

73. M. Hoehne,E. Schreier. Detection of Norovirus genogroup I and II by multiplex real-time RT- PCR using a 3'-minor groove binderDNA probe. BMC Infectious Diseases. 2006; 6(69-69.

74. M. L. Stewart, A. P. Grollman,M.-T. Huang. Aurintricarboxylic acid: inhibitor of initiation of protein synthesis. Proceedings of the National Academy of Sciences. 1971; 68(1): 97-101.

75. Y. Yap, X. Zhang, A. Andonov,R. He. Structural analysis of inhibition mechanisms of Aurintricarboxylic Acid on SARS-CoV polymerase and other proteins. Computational Biology and Chemistry. 2005; 29(3): 212-219.

76. G. J. Bartlett, C. T. Porter, N. Borkakoti, J. M. Thornton. Analysis of catalytic residues in enzyme active sites. Journal of Molecular Biology. 2002; 324(1): 105-121.
77. Vogelstein, K. W. Kinzler. Digital PCR. Proceedings of the National Academy of Sciences. 1999; 96(16): 9236-9241.

78. Bustin. Absolute quantification of mRNA using real-time reverse transcription polymerase chain reaction assays. J Mol Endocrinol. 2000; 25(2): 169-193.

79. S. G. Lee, S. H. Lee, S. W. Park, C. I. Suh, W. H. Jheong, S. Oh,S. Y. Paik. Standardized positive controls for detection of norovirus by reverse transcription PCR. Virol J. 2011; 8(260.

80. R. I. Glass, U. D. Parashar, M. K. Estes. Norovirus Gastroenteritis. New England Journal of Medicine. 2009; 361(18): 1776-1785.

81. R. Brennan, B. W. Matthews. The helix-turn-helix DNA binding motif. J Biol Chem. 1989; 264(4): 1903-1906.

82. H. Ohlendorf, B. W. Matthews. Structural studies of protein-nucleic acid interactions. Annu Rev Biophys Bioeng. 1983; 12(259-284.

83. Y. Takeda, D. H. Ohlendorf, W. F. Anderson,B. W. Matthews. DNA-binding proteins. Science. 1983; 221(4615): 1020-1026.

84. O. Pabo, R. T. Sauer. Protein-DNA recognition. Annu Rev Biochem. 1984; 53(293-321.

85. R. Schleif. DNA binding by proteins. Science. 1988; 241(4870): $1182-1187$.

86. R. Zhang, A. Joachimiak, C. Lawson, R. Schevitz, Z. Otwinowski, P. Sigler. The crystal structure of trp aporepressor at 1.8 A shows how binding tryptophan enhances DNA aflinity. Nature. 1987; 327(591597.

87. Z. Otwinowski, R. Schevitz, R. Zhang, C. Lawson, A. Joachimiak, R. Marmorstein, B. Luisi, P. Sigler. Crystal structure of trp represser/operator complex at atomic resolution. Nature. 1988; 335(6188): 321-329.

88. Yang, R. Yan, A. Roy, D. Xu, J. Poisson,Y. Zhang. The I-TASSER Suite: protein structure and function prediction. Nature methods. 2015; 12(1): 7-8.

89. Roy, A. Kucukural, Y. Zhang. I-TASSER: a unified platform for automated protein structure and function prediction. Nature protocols. 2010; 5(4): 725-738.

90. Y. Zhang. I-TASSER server for protein 3D structure prediction. BMC bioinformatics. 2008; 9(1):40

\section{How to cite this article:}

Wurtzler EM, Ravi R, Kapoor V, Wendell D. Rational Design of Duplex Specific Nuclease for One-Step Isothermal Viral RNA Detection. J App Biol Biotech. 2017; 5 (05): 1-10. 